\title{
The taxonomy of brain cancer stem cells: what's in a name?
}

\author{
David H. Gutmann ${ }^{1}$ \\ ${ }^{1}$ Department of Neurology, Washington University School of Medicine, St. Louis MO \\ Correspondence to: David H. Gutmann, email: gutmannd@neuro.wustl.edu \\ Keywords: progenitor cell, glioma, ependymoma, astrocytoma, cell-of-origin, subventricular zone \\ Received: April 25, $2013 \quad$ Accepted: March 31, $2014 \quad$ Published: March 31, 2014
}

This is an open-access article distributed under the terms of the Creative Commons Attribution License, which permits unrestricted use, distribution, and reproduction in any medium, provided the original author and source are credited.

\begin{abstract}
:
With the increasing recognition that stem cells play vital roles in the formation, maintenance, and potential targeted treatment of brain tumors, there has been an exponential increase in basic laboratory and translational research on these cell types. However, there are several different classes of stem cells germane to brain cancer, each with distinct capabilities and functions. In this perspective, we discuss the types of stem cells relevant to brain tumor pathogenesis, and suggest a nomenclature for future preclinical and clinical investigation.
\end{abstract}

\section{INTRODUCTION}

Brain cancers are the leading cause of cancer-related death in children and the fourth leading cause in adults [1-3]. Among the diverse histologic varieties of brain tumors, gliomas (glial cell neoplasms) comprise the most common subtype. Gliomas (or astrocytomas) are classified according to an established set of pathological features that define the four different malignancy grades, including low-grade (grades I and II) and high-grade (grades III and IV) tumors [4]. Unfortunately, there are limited effective therapeutic options available for these cancers, and individuals with these brain tumors experience significant morbidity and mortality [5-6]. While traditional anti-cancer therapies aim to kill rapidly dividing cells, complementary treatment strategies involve blocking the function of other cell types present in brain tumors [7]. As such, non-neoplastic astrocytes [8], blood vessels [9], and immune system-like cells (microglia and macrophages; [10-11]) each have been shown to participate in an instructive manner in glioma formation and progression. Leveraging this innate cellular heterogeneity, numerous studies have sought to define the individual contributions of these various stromal cell types to tumor formation and growth, leading to new brain tumor therapies [12-16].

Similarly, over the past decade, there has been an explosion in the number of publications describing the role of another of these cell types (stem cells) in the pathogenesis of glioma [17-18]. These investigations have revealed important functions for stem cells in glioma development, maintenance, and tumor heterogeneity. Because of their involvement in brain cancer, these stem cells are often collectively referred to as "cancer stem cells", despite the fact that they may have different tissue origins, functions, and contributions to glioma biology. To further complicate matters, the criteria used to define these cancer stem cells in glioma often differ from study to study, and variably include the ability to self-renew (generate new stem cells), the capacity to form neurospheres, the expression of "stem cell" markers, the ability to give rise to all three major central nervous system (CNS) cell types (oligodendrocytes, astrocytes, and neurons), the capacity to proliferate for prolonged periods of time in culture, and the ability to generate gliomas following implantation into the brains of immunocompromised rodents (Figure 1). Herein, the definition of the cancer stem cell will be reviewed and an alternative nomenclature proposed to enable future experimental study and clinical application.

\section{A matter of definition}

The ability to develop consensus criteria for a "cancer stem cell" depends on which of the various stem cell populations we are describing. For this reason, it is important to distinguish between the particular stem cell subtypes relevant to glioma formation, maintenance, and progression.

\section{Glioma initiating stem cells (GISCs).}

Emerging evidence from numerous laboratories using a diverse collection of genetically-engineered mouse (GEM) models supports the notion that low-grade 
and high-grade gliomas likely arise from neural stem cells (NSCs). These NSCs typically reside in germinal zones [19], such as the lateral ventricle subventricular zone (lvSVZ) [20-21], the third ventricle (TVZ) [22-24], and the fourth ventricle [25-26]. Even within these ventricular zones, there are discrete subregions and cell types most capable of giving rise to glioma following the introduction of glioma-causing genetic changes (mutations) [23, 2729]. In addition, some recent reports have suggested that not all gliomas arise from NSCs, such that gliomas can been initiated when astrocytes [30-31], oligodendrocyte progenitors [32-36], and even neurons [37] are targeted in experimental mouse model systems. While these more differentiated cell types do generate gliomas under specific conditions, it is not clear whether gliomagenesis requires a reversion to a more progenitor-like (stem cell) state from which glioma formation ensues [38]. Studies, such as those involving lineage tracing methods [33, 39], may help to resolve these issues. Nonetheless, glioma-initiating cells should have the same functional properties as the stem cells that normally reside in these germinal zones.

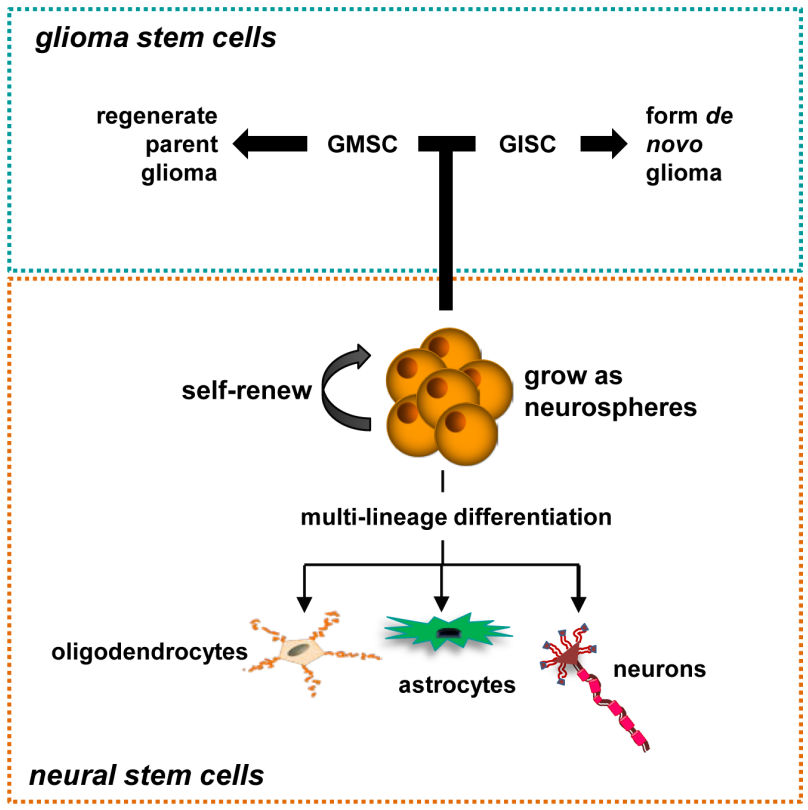

Figure 1: Stem Cells in Glioma. Properties of neural stem cells include self-renewal, multi-lineage differentiation, and the ability to grow as neurospheres. GMSCs have the capacity to self-renew at limiting dilutions, undergo multilineage differentiation, grow as neurospheres, and in some instances, give rise to gliomas following transplantation into immunocompromised hosts. Similarly, GISCs are capable of forming glioma in vivo following the acquisition of gliomacausing genetic mutations.

\section{Glioma maintaining stem cells (GMSCs).}

From fully-formed human glioma specimens, cells have been isolated with properties typically attributed to stem cells [40-42]. In the case of high-grade gliomas, these cancer stem cells are capable of generating histologicallysimilar tumors following implantation into naïve rodent recipients (Koch's postulate). However, despite considerable effort, such cells have not been isolated from low-grade gliomas, raising intriguing questions about the microenvironmental conditions required for low-grade glioma establishment. In this regard, low-grade gliomas are highly dependent on their non-neoplastic microenvironment (stroma), and require microglia and other stromal cell types to initiate gliomagenesis and maintain tumor growth in GEM strains [43-45]: The failure to serially passage low-grade gliomas (e.g., pilocytic astrocytomas) using neurosphere preparations may not indicate an absence of GMSCs, but rather that the obligate stromal conditions are not accurately recapitulated in immunocompromised rats and mice. Alternatively, these low-grade glioma stem cells may harbor specific mutations that favor senescence, thus limiting their longterm maintenance [46].

Moreover, stem cells that derive from fully-formed cancers do not need to have the same biological properties as their normal NSC counterparts. In this respect, some laboratories have reported that GMSCs lack the capacity to give rise to all three CNS cell types (multi-lineage differentiation) as well as exhibit new properties not shared with normal NSCs (e.g., relative resistance to chemotherapy or radiation; [47-50]). For example, while normal NSCs are normally quiescent, cancer-maintaining stem cells in some situations can still proliferate [5152]. In addition, there exists significant cancer stem cell heterogeneity in high-grade gliomas with respect to their cancer propagating ability [53]. Collectively, GMSCs represent those stem-like cells most capable of maintaining the tumor, such that their suppression limits glioma growth and increases the effectiveness of therapy.

\section{Glioma-associated stem cells (GASCs).}

In addition to stem cells harboring initiating gliomaassociated genetic mutations, there are also recruited stem cells in both human and experimental murine glioma tumors. These stem cells may originate from outside of the brain parenchyma (e.g., hematopoietic stem cells; [54]) or from stem cell niches within the CNS [55-56]. The homing of these stem cells to the developing tumor represents a natural response to CNS injury [57-58], such as occurs in the setting of cerebral ischemia (stroke; [59-61]) or multiple sclerosis (experimental allergic 
encephalomyelitis; [62-63]). The properties of these recruited stem cells thus reflect their region of origin (bone marrow, brain) in combination with remodeling that occurs as a result of adaptation to their newly adopted cellular environment. Aside from their potential therapeutic value as cellular payload delivery vehicles for oncolytic virus or chemotherapy [64-67], their function in glioma maintenance or response to treatment is unclear, with reports describing both glioma suppressing [68] and promoting [69] effects. Moreover, the markers used to define normal NSCs may not apply to those whose primary origins are outside of the brain.

\section{Knowing one when you see one}

Current methods for identifying glioma stem cells rely mainly on protein marker expression and functional assessments. Each of these methods is valid, but both have limitations, which are important to consider when classifying the diverse cellular populations that contribute to gliomagenesis and progression.

\section{Cellular phenotyping.}

One of the criteria used to define glioma stem cells is the expression of stem cell markers, including CD133 (prominin-1), sox2, Olig2, nestin, brain lipid binding protein (BLBP), and CD44, which derive from studies on both CNS and non-CNS progenitor cell populations [70-71]. However, it should be appreciated that none of these markers exclusively identify stem cells and all are expressed in different CNS cell types at varying times during brain development. For example, Olig2 is also expressed in oligodendrocyte progenitor cells, nestin in reactive astrocytes, CD44 in astrocytes and microglia, BLBP in radial glia, and sox2 in oligodendrocytes. CD133 (prominin-1) has been uniformly used to mark glioma stem cells; yet, CD133-negative tumor cells have also been reported to generate tumors under specific conditions [72]. As mentioned above, it seems logical to develop antibodybased reagents that can be used to study each of the stem cell populations relevant to glioma pathogenesis [73-74]. To this end, we and others have recently employed GEM glioma models to identify transcripts unique to GMSCs relative to their non-neoplastic NSC counterparts (GISCs).

In addition, converging data from several laboratories have revealed striking heterogeneity in progenitor (stem) cells from different regions of the CNS $[25,75-76]$, raising the possibility that stem cell markers may differ depending on the brain region (cortex versus cerebellum) or developmental age (adult versus infant). For example, discrete gene expression patterns separate NSCs from the third and lateral ventricles [23] as well as neuroglial progenitors (radial glia) from the spinal cord and brain [78-79].

\section{Functional phenotyping.}

The lumping of all glioma-related stem cells into one group assumes that they are all functionally similar. Since the roles they play in glioma pathogenesis may be remarkably different (tumor initiation versus tumor maintenance), it is also likely that their biological properties will be dissimilar and reflect these distinct roles. For example, glioma-initiating stem cells should, by definition, have the capabilities of normal NSCs, since the genetic alterations that created the cancers occurred in these very cells. However, once the tumor is formed, those stem cells may no longer have the properties found in their normal counterparts, as they have sustained a series of mutations that could potentially reprogram them and limit the capabilities of the resulting stem cell

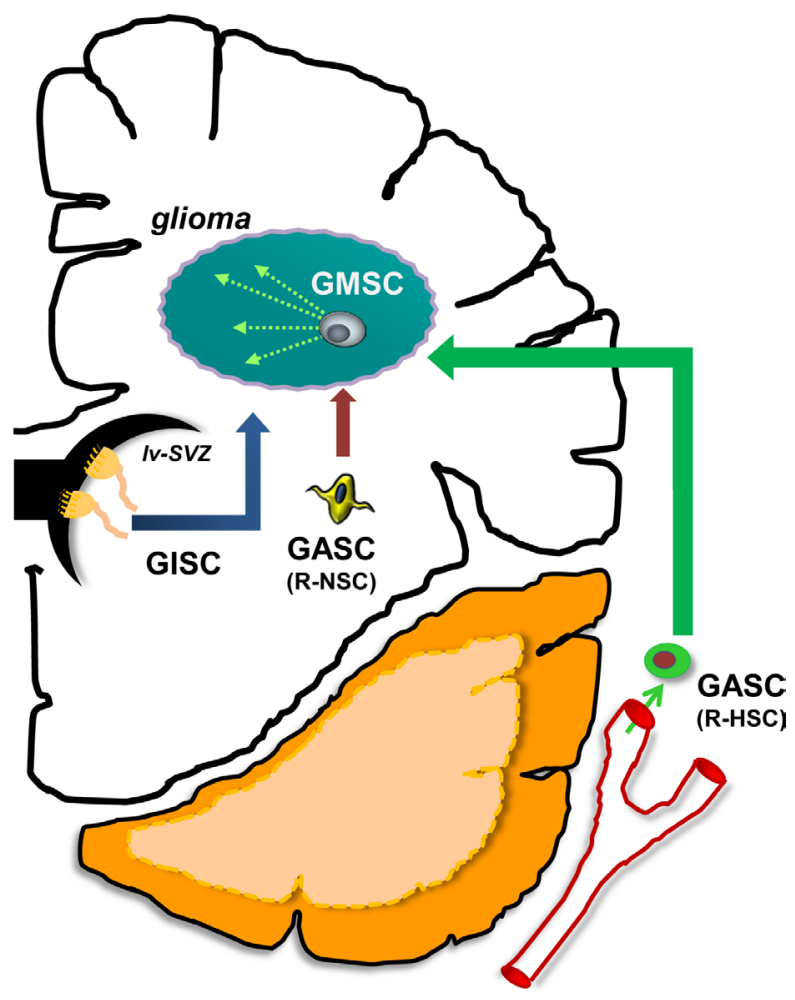

Figure 2: Several distinct populations of stem cells participate in glioma pathogenesis. Glioma-initiating stem cells (GISCs) originate from germinal zones and serve as the cellular substrates for gliomagenesis following the acquisition of cancer-initiating genetic mutations. Glioma-maintaining stem cells (GMSCs) are isolated from mature gliomas and can propagate these tumors following transplantation into naïve recipient brains. Glioma-associated stem cells (GASCs) are recruited from local (brain) or distant (hematopoietic stem cells; HSCs) sites to populate the brain tumor. 
progeny. In addition, for those cancers that arise following the introduction of genetic changes in more differentiated cells, it is possible that the reprogramming that ensued following the acquisition of the causative genetic changes results in cancer stem cells with properties more similar to de-differentiated cell types. Finally, as mentioned above, several studies using different experimental mouse glioma systems have revealed that NSCs from different locations within the CNS have differential capacities to increase their expansion and to form tumors following the introduction of glioma-associated genetic mutations [23, 77-79]. These findings further underscore the need to more fully appreciate the diversity of NSCs when characterizing glioma stem cell populations.

\section{Why it matters}

While it may appear to be an epistemological debate, defining the particular glioma stem cell has profound implications for the types of questions to be addressed. Employing definitions relevant for GMSCs to the study of GISCs is likely to create interpretation issues and may result in inaccurate experimental conclusions. For this reason, we propose a taxonomy system to facilitate more meaningful scientific inquiry and lead to improved translational impact (Figure 2).

As such, studies focused on cell of origin (GISCs) should consider applying criteria used to characterize progenitor cells from that region of the CNS during the relevant developmental period. In this regard, tumorinitiating cell investigations require a more in-depth understanding of the particular germinal zone from which the specific glioma derives. For pilocytic astrocytomas, characterizing the stem cell niches relevant to pediatric gliomagenesis (third and fourth ventricular zones) as well as defining the innate and stroma-influenced capabilities of these progenitors during early life is critical. Similarly, in the case of adult high-grade gliomas, the focus would be on adult progenitor populations in the ventricular zones (e.g., lateral ventricle or other gliomagenic regions, such as the subcortical white matter) thought to give rise to these tumors. Analogous approaches would also be leveraged to define GASCs, based on their tissue of origin and the impact that the tumor has on the function of these recruited stem cells.

In contrast, stem cells from fully-formed tumors would be expected to have different properties than those that served as the cells of origin for that malignancy. During the process of gliomagenesis, those GMSCs will have acquired new phenotypes conferred both by the glioma-associated genetic mutations, but also by the unique microenvironment in which the glioma resides. To identify the proteins and biological functions unique to GMSCs will require comparisons not only to non- neoplastic primary NSCs containing these mutations, but also a more complete appreciation of how the glioma stem cell niche influences the epigenetic and gene expression profiles of these cells. A careful dissection of each of these stem cell populations offers new opportunities to more fully understand glioma formation, maintenance, and treatment.

\section{REFERENCES}

1. Dolecek TA, Propp JM, Stroup NE, Kruchko C. CBTRUS Statistical Report: Primary brain and central nervous system tumors diagnosed in the United States in 2005-2009. NeuroOncol. 2012;14:1-49.

2. Patel S, Bhatnagar A, Wear C, Osiro S, Gabriel A, Kimball D, John A, Fields PJ, Tubbs RS, Loukas M. Are pediatric brain tumors on the rise in the USA? Significant incidence and survival findings from the SEER database analysis. Childs Nerv Syst. 2014;30:147-54.

3. Darefsky AS, Dubrow R. International variation in the incidence of adult primary malignant neoplasms of the brain and central nervous system. Cancer Causes Control. 2009;20:1593-604.

4. Louis DN, Ohgaki H, Wiestler OD, Cavenee WK. WHO Classifcation of Tumours of the Central Nervous System. IARC:Lyon, 2007.

5. Ramirez YP, Weatherbee JL, Wheelhouse RT, Ross AH. Glioblastoma multiforme therapy and mechanisms of resistance. Pharmaceuticals (Basel). 2013;6:1475-506.

6. Omuro A, DeAngelis LM. Glioblastoma and other malignant gliomas: a clinical review. JAMA. 2013;310:1842-50.

7. Charles NA, Holland EC, Gilbertson R, Glass R, Kettenmann H. The brain tumor microenvironment. Glia. 2011;59:1169-80.

8. Katz AM, Amankulor NM, Pitter K, Helmy K, Squatrito M, Holland EC. Astrocyte-specific expression patterns associated with the PDGF-induced glioma microenvironment. PLoS One. 2012; 7:e32453.

9. Hardee ME, Zagzag D. Mechanisms of glioma-associated neovascularization. Am J Pathol. 2012;181:1126-41.

10. Wei J, Gabrusiewicz K, Heimberger A. The controversial role of microglia in malignant gliomas. Clin Dev Immunol. 2013;2013:285246.

11. da Fonseca AC, Badie B. Microglia and macrophages in malignant gliomas: recent discoveries and implications for promising therapies. Clin Dev Immunol. 2013;2013:264124.

12. Rinne ML, Lee EQ, Nayak L, Norden AD, Beroukhim R, Wen PY, Reardon DA. Update on bevacizumab and other angiogenesis inhibitors for brain cancer. Expert Opin Emerg Drugs. 2013;18:137-53.

13. Sarkar S, Döring A, Zemp FJ, Silva C, Lun X, Wang 
X, Kelly J, Hader W, Hamilton M, Mercier P, Dunn JF, Kinniburgh D, van Rooijen N, Robbins S, Forsyth P, Cairncross G, Weiss S, Yong VW. Therapeutic activation of macrophages and microglia to suppress brain tumorinitiating cells. Nat Neurosci. 2014;17:46-55.

14. da Fonseca AC, Badie B. Microglia and macrophages in malignant gliomas: recent discoveries and implications for promising therapies. Clin Dev Immunol. 2013;2013:264124.

15. Badhiwala J, Decker WK, Berens ME, Bhardwaj RD. Clinical trials in cellular immunotherapy for brain/CNS tumors. Expert Rev Neurother. 2013;13:405-24.

16. Heimberger AB, Sampson JH. Immunotherapy coming of age: what will it take to make it standard of care for glioblastoma? Neuro Oncol. 2011;13:3-13.

17. Ahmed AU, Auffinger B, Lesniak MS. Understanding glioma stem cells: rationale, clinical relevance and therapeutic strategies. Expert Rev Neurother. 2013;13:54555.

18. Venere M, Fine HA, Dirks PB, Rich JN. Cancer stem cells in gliomas: identifying and understanding the apex cell in cancer's hierarchy. Glia. 2011;59:1148-54.

19. Quiñones-Hinojosa A, Sanai N, Soriano-Navarro M, Gonzalez-Perez O, Mirzadeh Z, Gil-Perotin S, RomeroRodriguez R, Berger MS, Garcia-Verdugo JM, AlvarezBuylla A. Cellular composition and cytoarchitecture of the adult human subventricular zone: a niche of neural stem cells. J Comp Neurol. 2006;494:415-34.

20. Alvarez-Buylla A, Kohwi M, Nguyen TM, Merkle FT. The heterogeneity of adult neural stem cells and the emerging complexity of their niche. Cold Spring Harb Symp Quant Biol. 2008;73:357-65.

21. Ponti G, Obernier K, Guinto C, Jose L, Bonfanti L, AlvarezBuylla A. Cell cycle and lineage progression of neural progenitors in the ventricular-subventricular zones of adult mice. Proc Natl Acad Sci USA. 2013;110:E1045-54.

22. Dahiya S, Lee DY, Gutmann DH. Comparative characterization of the human and mouse third ventricle germinal zones. J Neuropathol Exp Neurol. 2011;70:62233.

23. Lee DY, Gianino SM, Gutmann DH. Innate neural stem cell heterogeneity determines the patterning of glioma formation in children. Cancer Cell. 2012;22:131-8.

24. Robins SC, Stewart I, McNay DE, Taylor V, Giachino C, Goetz M, Ninkovic J, Briancon N, Maratos-Flier E, Flier JS, Kokoeva MV, Placzek M. $\alpha$-Tanycytes of the adult hypothalamic third ventricle include distinct populations of FGF-responsive neural progenitors. Nat Commun. 2013;4:2049.

25. Gibson P, Tong Y, Robinson G, Thompson MC, Currle DS, Eden C, Kranenburg TA, Hogg T, Poppleton H, Martin J, Finkelstein D, Pounds S, Weiss A, Patay Z, Scoggins M, Ogg R, Pei Y, Yang ZJ, Brun S, Lee Y, Zindy F,
Lindsey JC, Taketo MM, Boop FA, Sanford RA, Gajjar A, Clifford SC, Roussel MF, McKinnon PJ, Gutmann DH, Ellison DW, Wechsler-Reya R, Gilbertson RJ. Subtypes of medulloblastoma have distinct developmental origins. Nature. 2010;468:1095-9.

26. Bennett L, Yang M, Enikolopov G, Iacovitti L. Circumventricular organs: a novel site of neural stem cells in the adult brain. Mol Cell Neurosci. 2009;41:337-47.

27. Alcantara Llaguno S, Chen J, Kwon CH, Jackson EL, Li Y, Burns DK, Alvarez-Buylla A, Parada LF. Malignant astrocytomas originate from neural stem/progenitor cells in a somatic tumor suppressor mouse model. Cancer Cell. 2009; 15:45-56.

28. Jackson EL, Garcia-Verdugo JM, Gil-Perotin S, Roy M, Quinones-Hinojosa A, VandenBerg S, Alvarez-Buylla A. PDGFR alpha-positive B cells are neural stem cells in the adult SVZ that form glioma-like growths in response to increased PDGF signaling. Neuron. 2006;51:187-99.

29. Hegedus B, Dasgupta B, Shin JE, Emnett RJ, HartMahon EK, Elghazi L, Bernal-Mizrachi E, Gutmann DH. Neurofibromatosis-1 regulates neuronal and glial cell differentiation from neuroglial progenitors in vivo by both cAMP- and Ras-dependent mechanisms. Cell Stem Cell. 2007;1:443-57.

30. Bachoo RM, Maher EA, Ligon KL, Sharpless NE, Chan SS, You MJ, Tang Y, DeFrances J, Stover E, Weissleder R, Rowitch DH, Louis DN, DePinho RA. Epidermal growth factor receptor and Ink4a/Arf: convergent mechanisms governing terminal differentiation and transformation along the neural stem cell to astrocyte axis. Cancer Cell. 2002;1:269-77.

31. Dai C, Celestino JC, Okada Y, Louis DN, Fuller GN, Holland EC. PDGF autocrine stimulation dedifferentiates cultured astrocytes and induces oligodendrogliomas and oligoastrocytomas from neural progenitors and astrocytes in vivo. Genes Dev. 2001;15:1913-25.

32. Assanah M, Lochhead R, Ogden A, Bruce J, Goldman J, Canoll P. Glial progenitors in adult white matter are driven to form malignant gliomas by platelet-derived growth factor-expressing retroviruses. J Neurosci. 2006;26:678190.

33. Liu C, Sage JC, Miller MR, Verhaak RG, Hippenmeyer S, Vogel H, Foreman O, Bronson RT, Nishiyama A, Luo L, Zong $\mathrm{H}$. Mosaic analysis with double markers reveals tumor cell of origin in glioma. Cell. 2011;146:209-21.

34. Persson AI, Petritsch C, Swartling FJ, Itsara M, Sim FJ, Auvergne R, Goldenberg DD, Vandenberg SR, Nguyen KN, Yakovenko S, Ayers-Ringler J, Nishiyama A, Stallcup WB, Berger MS, Bergers G, McKnight TR, Goldman SA, Weiss WA. Non-stem cell origin for oligodendroglioma. Cancer Cell. 2010;18:669-82.

35. Wang J, Bushman J, Wang X, Mayer-Proschel M, Johnson M, Noble M. Oligodendrocyte/type-2 astrocyte progenitor 
cells and glial-restricted precursor cells generate different tumor phenotypes in response to the identical oncogenes. J Neurosci. 2013;33:16805-17.

36. Lindberg N, Kastemar M, Olofsson T, Smits A, Uhrbom L. Oligodendrocyte progenitor cells can act as cell of origin for experimental glioma. Oncogene. 2009;28:2266-75.

37. Friedmann-Morvinski D, Bushong EA, Ke E, Soda Y, Marumoto T, Singer O, Ellisman MH, Verma IM. Dedifferentiation of neurons and astrocytes by oncogenes can induce gliomas in mice. Science. 2012;338:1080-4.

38. Uhrbom L, Dai C, Celestino JC, Rosenblum MK, Fuller GN, Holland EC. Ink4a-Arf loss cooperates with KRas activation in astrocytes and neural progenitors to generate glioblastomas of various morphologies depending on activated Akt. Cancer Res. 2002;62:5551-8.

39. Beckervordersandforth R, Deshpande A, Schaffner I, Huttner HB, Lepier A, Lie DC, Gotz M. In vivo targeting of adult neural stem cells in the dentate gyrus by a split-Cre approach. Stem Cell Reports. 2:153-62, 2014.

40. Galli R, Binda E, Orfanelli U, Cipelletti B, Gritti A, De Vitis S, Fiocco R, Foroni C, Dimeco F, Vescovi A. Isolation and characterization of tumorigenic, stem-like neural precursors from human glioblastoma. Cancer Res. 2004;64:7011-21.

41. Singh SK, Clarke ID, Terasaki M, Bonn VE, Hawkins C, Squire J, Dirks PB. Identification of a cancer stem cell in human brain tumors. Cancer Res. 2003;63:5821-8.

42. Singh SK, Hawkins C, Clarke ID, Squire JA, Bayani J, Hide T, Henkelman RM, Cusimano MD, Dirks PB. Identification of human brain tumour initiating cells. Nature. 2004;432:396-401.

43. Bajenaru ML, Hernandez MR, Perry A, Zhu Y, Parada LF, Garbow JR, Gutmann DH. Optic nerve glioma in mice requires astrocyte $\mathrm{Nf1}$ gene inactivation and $\mathrm{Nf1}$ brain heterozygosity. Cancer Res. 2003;63:8573-7.

44. Daginakatte GC, Gutmann DH. Neurofibromatosis-1 (Nf1) heterozygous brain microglia elaborate paracrine factors that promote Nf1-deficient astrocyte and glioma growth. Hum Mol Genet. 2007;16:1098-112.

45. Pong WW, Higer SB, Gianino SM, Emnett RJ, Gutmann DH. Reduced microglial CX3CR1 expression delays neurofibromatosis-1 glioma formation. Ann Neurol. 2013; $73: 303-8$.

46. Raabe EH, Lim KS, Kim JM, Meeker A, Mao XG, Nikkhah G, Maciaczyk J, Kahlert U, Jain D, Bar E, Cohen KJ, Eberhart CG. BRAF activation induces transformation and then senescence in human neural stem cells: a pilocytic astrocytoma model. Clin Cancer Res. 2011;17:3590-9.

47. Liu G, Yuan X, Zeng Z, Tunici P, Ng H, Abdulkadir IR, Lu L, Irvin D, Black KL, Yu JS. Analysis of gene expression and chemoresistance of CD133+ cancer stem cells in glioblastoma. Mol Cancer. 2006;5:67.

48. Bleau AM, Hambardzumyan D, Ozawa T, Fomchenko
EI, Huse JT, Brennan CW, Holland EC. PTEN/PI3K/ Akt pathway regulates the side population phenotype and ABCG2 activity in glioma tumor stem-like cells. Cell Stem Cell. 2009;4:226-35.

49. Hambardzumyan D, Squatrito M, Holland EC. Radiation resistance and stem-like cells in brain tumors. Cancer Cell. 2006;10:454-6.

50. Salmaggi A, Boiardi A, Gelati M, Russo A, Calatozzolo C, Ciusani E, Sciacca FL, Ottolina A, Parati EA, La Porta C, Alessandri G, Marras C, Croci D, De Rossi M. Glioblastoma-derived tumorospheres identify a population of tumor stem-like cells with angiogenic potential and enhanced multidrug resistance phenotype. Glia. 2006;54:850-60.

51. Blagosklonny MV. Target for cancer therapy: proliferating cells or stem cells. Leukemia. 2006;20:385-91.

52. Blagosklonny MV. Cancer stem cell and cancer stemloids: from biology to therapy. Cancer Biol. Ther. 2007;6:168490.

53. Stieber D, Golebiewska A, Evers L, Lenkiewicz E, Brons NH, Nicot N, Oudin A, Bougnaud S, Hertel F, Bjerkvig R, Vallar L, Barrett MT, Niclou SP. Glioblastomas are composed of genetically divergent clones with distinct tumourigenic potential and variable stem cell-associated phenotypes. Acta Neuropathol. 2014;127:203-19.

54. Behnan J, Isakson $\mathrm{P}$, Joel M, Cilio C, Langmoen IA, Vik-Mo EO, Badn W. Recruited brain tumor-derived mesenchymal stem cells contribute to brain tumor progression. Stem Cells. 2013 Epub Dec 3.

55. Glass R, Synowitz M, Kronenberg G, Walzlein JH, Markovic DS, Wang LP, Gast D, Kiwit J, Kempermann G, Kettenmann H. Glioblastoma-induced attraction of endogenous neural precursor cells is associated with improved survival. J Neurosci. 2005;25:2637-46.

56. Honeth G, Staflin K, Kalliomäki S, Lindvall M, Kjellman C. Chemokine-directed migration of tumor-inhibitory neural progenitor cells towards an intracranially growing glioma. Exp Cell Res. 2006;312:1265-76.

57. Sun L, Lee J, Fine HA. Neuronally expressed stem cell factor induces neural stem cell migration to areas of brain injury. J Clin Invest. 2004;113:1364-74.

58. Tajiri N, Acosta SA, Shahaduzzaman M, Ishikawa H, Shinozuka K, Pabon M, Hernandez-Ontiveros D, Kim DW, Metcalf C, Staples M, Dailey T, Vasconcellos J, Franyuti G, Gould L, Patel N, Cooper D, Kaneko Y, Borlongan CV, Bickford PC. Intravenous transplants of human adiposederived stem cell protect the brain from traumatic brain injury-induced neurodegeneration and motor and cognitive impairments: cell graft biodistribution and soluble factors in young and aged rats. J Neurosci. 2014;34:313-26.

59. Ohab JJ, Fleming S, Blesch A, Carmichael ST. A neurovascular niche for neurogenesis after stroke. J 
Neurosci. 2006;26:13007-16.

60. Andres RH, Choi R, Pendharkar AV, Gaeta X, Wang N, Nathan JK, Chua JY, Lee SW, Palmer TD, Steinberg GK, Guzman R. The CCR2/CCL2 interaction mediates the transendothelial recruitment of intravascularly delivered neural stem cells to the ischemic brain. Stroke. 2011;42:2923-31.

61. Imitola J, Raddassi K, Park KI, Mueller FJ, Nieto M, Teng YD, Frenkel D, Li J, Sidman RL, Walsh CA, Snyder EY, Khoury SJ. Directed migration of neural stem cells to sites of CNS injury by the stromal cell-derived factor 1alpha/ CXC chemokine receptor 4 pathway. Proc Natl Acad Sci USA. 2004;101:18117-22.

62. Pluchino S, Quattrini A, Brambilla E, Gritti A, Salani G, Dina G, Galli R, Del Carro U, Amadio S, Bergami A, Furlan R, Comi G, Vescovi AL, Martino G. Injection of adult neurospheres induces recovery in a chronic model of multiple sclerosis. Nature. 2003;422:688-94.

63. Carbajal KS, Schaumburg C, Strieter R, Kane J, Lane TE. Migration of engrafted neural stem cells is mediated by CXCL12 signaling through CXCR4 in a viral model of multiple sclerosis. Proc Natl Acad Sci USA. 2010;107:11068-73.

64. Altaner C, Altanerova V. Stem cell based glioblastoma gene therapy. Neoplasma. 2012;59:756-60.

65. Sasportas LS, Kasmieh R, Wakimoto H, Hingtgen S, van de Water JA, Mohapatra G, Figueiredo JL, Martuza RL, Weissleder R, Shah K. Assessment of therapeutic efficacy and fate of engineered human mesenchymal stem cells for cancer therapy. Proc Natl Acad Sci USA. 2009;106:4822-7.

66. Ahmed AU, Thaci B, Tobias AL, Auffinger B, Zhang L, Cheng Y, Kim CK, Yunis C, Han Y, Alexiades NG, Fan X, Aboody KS, Lesniak MS. A preclinical evaluation of neural stem cell-based cell carrier for targeted antiglioma oncolytic virotherapy. J Natl Cancer Inst. 2013;105:968-77.

67. Zhou J, Patel TR, Sirianni RW, Strohbehn G, Zheng MQ, Duong N, Schafbauer T, Huttner AJ, Huang Y, Carson RE, Zhang Y, Sullivan DJ Jr, Piepmeier JM, Saltzman WM. Highly penetrative, drug-loaded nanocarriers improve treatment of glioblastoma. Proc Natl Acad Sci USA. 2013;110:11751-6.

68. Ho IA, Toh HC, Ng WH, Teo YL, Guo CM, Hui KM, Lam PY. Human bone marrow-derived mesenchymal stem cells suppress human glioma growth through inhibition of angiogenesis. Stem Cells. 2013;31:146-55.

69. Waterman RS, Henkle SL, Betancourt AM. Mesenchymal stem cell 1 (MSC1)-based therapy attenuates tumor growth whereas MSC2-treatment promotes tumor growth and metastasis. PLoS One. 2012;7:e45590.

70. Dirks PB. Brain tumor stem cells: the cancer stem cell hypothesis writ large. Mol Oncol. 2010;4:420-30.

71. Dell'Albani P. Stem cell markers in gliomas. Neurochem
Res. 2008;33:2407-15.

72. Chen R, Nishimura MC, Bumbaca SM, Kharbanda S, Forrest WF, Kasman IM, Greve JM, Soriano RH, Gilmour LL, Rivers CS, Modrusan Z, Nacu S, Guerrero S, Edgar KA, Wallin JJ, Lamszus K, Westphal M, Heim S, James CD, VandenBerg SR, Costello JF, Moorefield S, Cowdrey CJ, Prados M, Phillips HS.A hierarchy of self-renewing tumor-initiating cell types in glioblastoma. Cancer Cell. 2010;17:362-75.

73. Sandberg CJ, Altschuler G, Jeong J, Strømme KK, Stangeland B, Murrell W, Grasmo-Wendler UH, Myklebost O, Helseth E, Vik-Mo EO, Hide W, Langmoen IA. Comparison of glioma stem cells to neural stem cells from the adult human brain identifies dysregulated Wntsignaling and a fingerprint associated with clinical outcome. Exp Cell Res. 2013;319:2230-43.

74. Engström PG, Tommei D, Stricker SH, Ender C, Pollard SM, Bertone P. Digital transcriptome profiling of normal and glioblastoma-derived neural stem cells identifies genes associated with patient survival. Genome Med. 2012;4:76.

75. Sharma MK, Mansur DB, Reifenberger G, Perry A, Leonard JR, Aldape KD, Albin MG, Emnett RJ, Loeser S, Watson MA, Nagarajan R, Gutmann DH. Distinct genetic signatures among pilocytic astrocytomas relate to their brain region origin. Cancer Res. 2007;67:890-900.

76. Hitoshi S, Tropepe V, Ekker M, van der Kooy D. Neural stem cell lineages are regionally specified, but not committed, within distinct compartments of the developing brain. Development. 2002;129:233-44.

77. Lee DY, Yeh TH, Emnett RJ, White CR, Gutmann DH. Neurofibromatosis-1 regulates neuroglial progenitor proliferation and glial differentiation in a brain regionspecific manner. Genes Dev. 2010;24:2317-29.

78. Johnson RA, Wright KD, Poppleton H, Mohankumar KM, Finkelstein D, Pounds SB, Rand V, Leary SE, White E, Eden C, Hogg T, Northcott P, Mack S, Neale G, Wang YD, Coyle B, Atkinson J, DeWire M, Kranenburg TA, Gillespie Y, Allen JC, Merchant T, Boop FA, Sanford RA, Gajjar A, Ellison DW, Taylor MD, Grundy RG, Gilbertson RJ. Cross-species genomics matches driver mutations and cell compartments to model ependymoma. Nature. 466:632-6, 2010.

79. Taylor MD, Poppleton H, Fuller C, Su X, Liu Y, Jensen P, Magdaleno S, Dalton J, Calabrese C, Board J, Macdonald T, Rutka J, Guha A, Gajjar A, Curran T, Gilbertson RJ. Radial glia cells are candidate stem cells of ependymoma. Cancer Cell. 8:323-35, 2005. 